\title{
The novel inhibitor BRM270 downregulates tumorigenesis by suppression of NF-kB signaling cascade in MDR-induced stem like cancer-initiating cells
}

\author{
RAJ KUMAR MONGRE ${ }^{1}$, SIMRINDER SINGH SODHI ${ }^{1}$, MRINMOY GHOSH $^{1}$, \\ JEONG HYUN KIM ${ }^{1}$, NAMEUN KIM ${ }^{1}$, YANG HO PARK ${ }^{2}$, SUNG JIN KIM ${ }^{3}$, \\ YOO JEONG HEO ${ }^{2}$, NEELESH SHARMA ${ }^{4}$ and DONG KEE JEONG ${ }^{1}$
}

\begin{abstract}
${ }^{1}$ Laboratory of Animal Genetic Engineering and Stem Cell Biology, Department of Animal Biotechnology, Faculty of Biotechnology, Jeju National University, Jeju; ${ }^{2} \mathrm{BRM}$ Institute; ${ }^{3} \mathrm{CHA}$ Cancer Institute, CHA University, Seoul, Republic of Korea; ${ }^{4}$ Division of Veterinary Medicine, Faculty of Veterinary Science and Animal Husbandry, Sher-e-Kashmir University of Agricultural Sciences and Technology, R.S. Pura, Jammu, India
\end{abstract}

Received February 9, 2015; Accepted March 30, 2015

DOI: 10.3892/ijo.2015.2961

\begin{abstract}
The nuclear factor $\kappa \mathrm{B}(\mathrm{NF}-\kappa \mathrm{B})$ and interleukin-6 (IL-6) contribute to multidrug resistance (MDR) in tumor chemotherapy. The essential phenomenon of oncogenic activation of NF- $\mathrm{NB}$ in cancer-initiating cells showing MDR resulting from increased IL-6 expression is still unclear. Cancer stem cells (CSCs) have been the objective of intensive study. The aim of this study was to investigate the selective and potential efficacy of BRM270 against stem-like cancerinitiating cells (SLCICs) via the molecular mechanisms of its anticancer effects. Co-regulation of NF- $\kappa \mathrm{B}$ and $\mathrm{Cdk} 6$ might be new arena to mitigate tumorigenesis. In the present study phyto-drug based approach provides a new avenue in understanding the amelioration and regulatory mechanisms in CSCs. In the present study, an in vivo tumor metastasis model of osteosarcoma was established by injecting Cal72 and SaOS-2 SLCICs into the right lower flank of nude mice. Later the development of tumor was analyzed by LICOR Biosciences (Pearl image analyzer). Significant suppression of activation of NF- $\kappa \mathrm{B}$ and LPS-induced gene expression and apoptosis by BRM270 was confirmed by FACS, western blotting and qPCR. Further, both p65 and Cdk6 were significantly $(\mathrm{P}<0.05)$ overexpressed in BRM270 non-treated Cal72 SLCICs compared to treated group. BRM270 directly dephosphorylated RelA and selectively inhibited $N F-\kappa B$ transcriptional activity, resulting in decreased expression of interleukin-6, a
\end{abstract}

Correspondence to: Professor Dong Kee Jeong, Department of Animal Biotechnology, Faculty of Biotechnology, Jeju National University, Ara-1 Dong, Jeju-city, Jeju-Do 690-756, Republic of Korea E-mail: dkjeong@jejunu.ac.kr

Key words: stem like cancer-initiating cells, programmed cell death, mitotic catastrophe, multidrug resistance, pyknosis, karyorrhexis, cytoplasm shrinkage cytokine implicated in cancer metastasis. BRM270-mediated cell shrinkage, pyknosis, karyorrhexis and programmed cell death (PCD) were observed by Hoechst 33342 staining while flow cytometry analysis showed significant $(\mathrm{P}<0.05)$ decrease in cell population from $\mathrm{G} 0-\mathrm{G} 1$ phases. These findings suggest that activation of the oncogenic Cdk6-NF- $\mathrm{B}$ pathway, resulting from increased IL-6 expression, plays a central role in CD133 expressing SLCICs augmented MDR and neoplasia. This study proposes targeting of NF- $\kappa \mathrm{B}$, and Cdk6 with IL-6 as potential targets for PCD and treatment of chemotherapeutic resistance of CSCs to design novel therapies for their elimination.

\section{Introduction}

The cancer stem cells (CSCs) or stem like cancer-initiating cells (SLCICs) are thought to be responsible for cancer initiation, progression, drug resistance, recurrence and metastasis (1). SLCICs have multiple unique features which make them vital for tumor formation and self-renewal $(1,2)$. Specific surface biomarkers for distinct phenotypes can be used to distinguish SLCICs from other tumor and normal stem cells (3). However, cancer stem cells are mediators of recurrence which can be proliferated to any type of neoplasia. Therefore, methods for identifying and targeting such cells will represent a significant advancement in cancer therapy. Conceptually, SLCICs are known as tumor stem cells (TSCs) and tumor initiating cells (TICs) (4). CD133 molecule (trans-membrane protein Prominin 1) is a common and ubiquitous biomarker for endothelial progenitor cells, hematopoietic stem cells, glioblastoma, neuronal glial stem cells and different body organs (5-8). In addition, apart from CD133, 11 proteins have been proposed as potential differentiation biomarkers for SLCICs (9).

The multistep phenomena of carcinogenesis exhibit fragmention into constitutive cell division, proliferation, growth and survival stages $(10,11)$. The molecular diatomous mechanisms are mediated through the inactivation of many tumor suppressor genes and oncogenic mutations $(10,11)$. 
Pathophysiology of tumorigenesis has manifested that several transcription factors are involved in tumor progressions. One of the most important transcription factor (TF), NF- $\mathrm{B}$ plays a causative role but meager information is available on its mechanisms. NF- $\kappa \mathrm{B}$, a transcription factor significantly regulates the expression of anti-apoptotic genes, activates different pro-inflammatory cytokines and chemokines including IL-6 (12-14). It is a key molecular link between inflammation, initiation and progression of oncogenesis (12). Moreover, IL-6 is also known to have significant role in the cell cycle (13).

Recent studies on phytodrug-based approaches have opened a new avenue for the understanding of the amelioration and regulatory mechanisms in SLCICs. BRM270 is a one of the promising anticancer medicinal plant extract. It is widely distributed in Northeast Asia mainly China, Korea and Japan (15-17). It is a well-known traditional Chinese medicine, which is used to treat variety of diseases and cancers (15-19). Therefore, the present study was planned to know the efficacy of BRM270 to inhibit the cyclin-dependent cell division kinase-6. Further, the role of BRM270 in IL-6 mediated activation of multidrug resistance (MDR) in NF- $\mathrm{NB}$ signaling cascade of SLCICs was studied to judge its role as an inhibitor of NF- $\kappa \mathrm{B}$. To the best of our knowledge this is one of the first studies where efficacy of BRM270 as an anticancer product under in vitro and in vivo conditions was studied.

\section{Materials and methods}

Animal preparation and bioethics statement. For the present study, 10 (6-week-old) male NOD-SCID (BALB/cSIc (nu/nu), nude mice were procured from Japan SLC, Inc. They were housed in similar environmental and nutritional conditions. Mice were sacrificed at 11 weeks of age, according to the standard protocols of Jeju National University, Jeju-si, Jeju-do, Korea. The research proposal and the relevant experimental procedures were approved by the institutional review board of the Department of Animal Biotechnology, Jeju National University, Jeju-si, Jeju-do, Korea. All animal studies were conducted to induce tumors. In order to design tumorigenesis induction experiments, the mice were divided into three groups. Two mice were grouped as a negative control (NC), the rest were divided in two treatment groups, the Cal72 group $(n=4)$ and the SaOS-2 group $(n=4)$. Furthermore, $4 \times 10^{6} / \mathrm{ml}$ of SLCICs were suspended in Matrigel and injected subcutaneously into the right lower flank of the nude mouse in both the treatment groups.

Cell lines. Human osteosarcoma Cal72 and SaOS-2 cell lines were purchased from Korean Cell Bank (Seoul, Korea). These cell lines were routinely cultured in Dulbecco's modified Eagle's medium (DMEM) supplemented with $10 \%$ fetal bovine serum (FBS) (Hyclone, South Logan, UT, USA), $1 \%$ antibiotic-antimycotic (Gibco, Invitrogen, Carlsbad, CA, USA) at humidified $37^{\circ} \mathrm{C}$ and $5 \% \mathrm{CO}_{2}$ atmosphere. The cells were sub-cultured after attaining confluency of $80 \%$. For the present study, the cells in passages 9 and 12 were used. Human bone marrow cells (hBMCs) were also used as control.

Isolation and characterization of Cal72, SaOS-2 SLCICs and hBMCs. The population of CD133 expressed in Cal72 and
SaOS-2 cells was isolated by anti-human CD133 MicroBead kit (Miltenyi Biotec Corp., Auburn, CA, USA) using Midi MACS separator (Miltenyi Biotec Corp.) by following the user instruction manual. The hBMCs were isolated from the adult human bone marrow (Jeju National University Hospital, Jeju, Korea) and were separated by Ficoll-paque density gradient centrifugation (GE Healthcare Life Science, Piscataway, NJ, USA). The potential hBMCs were cultured in DMEM supplied with $10 \%$ FBS, $1 \%$ antibiotic-antimycotic and $10 \mathrm{nM}$ epithelial growth factor (Sigma-Aldrich Corp., St. Louis, MO, USA). The hBMCs from 3rd and 4th passage were confirmed as normal control cells against the efficacy of BRM270.

Preparation of nuclear and cytosolic protein extracts. A pellet of $1 \times 10^{7}$ cells was cultured to $80 \%$ confluency, then cells were treated with BRM270. Later, BRM270-treated or non-treated vs lipopolysaccharide (LPS) + BRM270 treated samples of Cal72 and SaOS-2 SLCICs were lysed with $400 \mu \mathrm{l}$ of $10 \mathrm{mM}$ $\mathrm{KCl}, 0.2 \mathrm{mMEDTA}, 1.5 \mathrm{mM} \mathrm{MgCl}_{2}, 0.5 \mathrm{mM}$ DTT and $0.2 \mathrm{mM}$ $\mathrm{PMSF}$ at $4^{\circ} \mathrm{C}$ for $10 \mathrm{~min}$. The lysate was centrifuged for $5 \mathrm{~min}$ at $12,000 \mathrm{x} \mathrm{g}$ and supernatants were stored as cytosolic extract at $-80^{\circ} \mathrm{C}$. The resulting pellet was re-suspended in $100 \mu \mathrm{l}$ of ice-cold $20 \mathrm{mM}$ HEPES ( $\mathrm{pH} 7.9$ ), $420 \mathrm{mM} \mathrm{NaCl}, 1.5 \mathrm{mM}$ $\mathrm{MgCl}_{2}, 20 \%$ (v/v) glycerol, $0.5 \mathrm{mM}$ DTT, $0.2 \mathrm{mM}$ EDTA and $0.2 \mathrm{mM}$ PMSF. After incubation at $4^{\circ} \mathrm{C}$ for $20 \mathrm{~min}$, the lysate was centrifuged for $10 \mathrm{~min}$ at $12,000 \mathrm{x} \mathrm{g}$ and the supernatant was stored as a nuclear extract at $-80^{\circ} \mathrm{C}$. The concentration of cytosolic and nuclear extract was determined using a BCA kit (Bio-Rad, Richmond, CA, USA).

Cytotoxicity assay. Suspended cells $(100 \mu \mathrm{l})$ at density of 5,000 cells/well were seeded in 96-well plate (Nunc ${ }^{\mathrm{TM}}$, Wiesbaden, Germany). After $24 \mathrm{~h}$ of recovery the cells were incubated in humid atmosphere at $37^{\circ} \mathrm{C}$ and $5 \% \mathrm{CO}_{2}$ and treated with BRM270. The BRM270 was procured from the Biological Response Modifier International Heath Town Corp., Korea. The cells were treated with varying concentrations of BRM270 such as 15.6-125 $\mu \mathrm{g} / \mathrm{ml}$ and doxorubicin (Dox) $5 \mu \mathrm{M} / \mathrm{ml}$ in MTT assay while $125 \mu \mathrm{g} / \mathrm{ml}$ in rest of the experiments were incubated for $24 \mathrm{~h}$. The enhanced cell viability assay was conducted with EZ-CyTox kit (Daeil Lab Service Co., Seoul, Korea) to measure the viable cells. EZ-CyTox solution $(10 \mu \mathrm{l})$ was added to each well and then cells were incubated for $4 \mathrm{~h}$ at $37^{\circ} \mathrm{C}$ and $5 \% \mathrm{CO}_{2}$. The light absorbance was determined at $450 \mathrm{~nm}$ by the Model 680 microplate-reader (Bio-Rad, Berkeley, CA, USA).

DNA fragmentation assay. CD133 expressing Cal72 and SAOS2 cells $\left(1 \times 10^{6}\right.$ cells) were seeded in 6-well microtitre plate (Nunc Nunclon ${ }^{\mathrm{TM}}$ Delta, USA). Then the cells were treated with the $125 \mu \mathrm{g} / \mathrm{ml}$ concentrations of BRM270 for $24 \mathrm{~h}$. For analysis of genomic DNA, attached and floating cells in the supernatant were harvested and collected. Genomic DNA was extracted by AccuPrep ${ }^{\circledR}$ Genomic DNA Extraction kit (Bioneer). DNA (5 $\mu \mathrm{g})$ was separated on a $1.2 \%$ agarose gel. DNA in the gel was stained with ethidium bromide and was visualized under UV light.

Apoptotic morphological changes in the nuclear chromatin of the cancer stem cells were stained by Hoechst 33258 . The 
cells were seeded in sterile 6-well plates (Nunc Nunclon Delta). After overnight growth, cells were treated with BRM270. Later, the cells were washed with $1 \mathrm{X}$ phosphate-buffered saline (10X PBS Gibco, Life Technologies ${ }^{\mathrm{TM}}$, USA) and were fixed with $4 \%$ paraformaldehyde for $10 \mathrm{~min}$ followed by incubation with $50 \mu \mathrm{M}$ Hoechst 33258 staining solution for $5 \mathrm{~min}$. After three washes with cold PBS, the cells were viewed under a fluorescence microscope (Olympus, IX-70, and Japan).

Apoptosis assay by flow cytometry. Cells $\left(1 \times 10^{5}\right)$ suspended in $2 \mathrm{ml}$ fresh media were seeded in each well of a 6-well flat-bottomed microtiter plate and incubated overnight. Then BRM270 with $125 \mu \mathrm{g} / \mathrm{ml}$ was added. After $24 \mathrm{~h}$, cells were harvested and washed twice with pre-cold PBS followed by re-suspension in $1 \mathrm{X}$ binding buffer at a concentration of $1 \times 10^{6}$ cells $/ \mathrm{ml}$. One hundred microliters of such solution (1x10 cells) was mixed with $5 \mu 1$ of Annexin V-FITC and $5 \mu \mathrm{l}$ of propidium iodide (PI, BD Biosciences, San Jose, CA, USA) according to the manufacturer's instructions. The mixed solution was incubated at room temperature $\left(25^{\circ} \mathrm{C}\right)$ in the dark for $15 \mathrm{~min}$. Then $400 \mu \mathrm{l}$ of $1 \mathrm{X}$ dilution buffer was added to each tube. Analysis was performed by Beckman Coulter FC500 Flow Cytometry System with CXP Software (Beckman Coulter, Fullerton, CA, USA) within $1 \mathrm{~h}$ of the treatment of cells with dilution buffer.

Cell cycle analysis. The analysis of cell cycle was detected by PI staining and analysis was performed by flow cytometry using a fluorescence-activated cell sorting (FACS) caliber (Becton-Dickinson). Subsequent to the treatment with $125 \mu \mathrm{g} / \mathrm{ml}$ and $5 \mu \mathrm{M} / \mathrm{ml}$ concentrations of BRM270 and Dox for $24 \mathrm{~h}$, the hBMCs, CD133 expressing Cal72 and SaOS-2 SLCICs were harvested at concentration of $1 \times 10^{6}$ cells $/ \mathrm{ml}$. The cells were fixed in $70 \%$ ethanol and incubated at $4^{\circ} \mathrm{C}$ overnight. The fixed cells were washed twice with cold PBS and then incubated for 30 min with Ribonuclease A (\#R-5125, Sigma, $8 \mu \mathrm{g} / \mathrm{ml})$ and PI $(10 \mu \mathrm{g} / \mathrm{ml})$. Then the cell samples were transferred to meshed blue capped tubes (BD Falcon ${ }^{\mathrm{TM}}$ Tubes \#352235). Later, the fluorescent signals were detected through the FL2 channel and the proportion of DNA that was present in the various phases was analyzed using ModfitLT Version 3.0 (Verity Software House, Topsham, ME, USA).

Quantitative real-time polymerase chain reaction ( $q P C R)$. The cells were detached by $0.5 \%$ trypsin-EDTA (Gibco) and total RNA was extracted by easyBlue (Intron Biotech, Seongnam-si, Gyeonggi-do, Korea). The purified RNA was quantified by using photometer (Bio-Rad Hercules, CA, USA). Purified RNA $(1 \mu \mathrm{g})$ was subjected to first strand cDNA synthesis using Superscript III first-strand cDNA synthesis kit and Oligo dT primer (Invitrogen). The cDNA was subjected to qPCR for the quantification of the relative transcript levels of NF- $\kappa B(p 65)$ and its inhibitor $(\mathrm{I} \kappa \mathrm{B} \alpha)$, structural maintenance of chromosome protein 2 (SMC-2), inflammatory cytokine IL-6 as well as pro-apoptotic gene/anti-apoptotic gene caspase-8 (Casp-8) using the specific primers (Table I).

Immunofluorescence staining. CD133 expressing Ca172 and SaOS-2 SLCICs were grown in 4-well chambered slide with glass coverslips (SPL Life Sciences Co., Ltd., Korea,
30104 PS/Glass/PP). The cells were cultured with BRM270 $(125 \mu \mathrm{g} / \mathrm{ml})$ and as non-treated (negative control) in DMEM high glucose medium for $24 \mathrm{~h}$. The next day cells were washed with cold $1 \mathrm{X}$ PBS and were fixed with $4 \%$ paraformaldehyde for $15 \mathrm{~min}$. Following this step the cells were permeabilized with $0.2 \%$ Triton X-100 for $10 \mathrm{~min}$. After washing with the PBS, cells were blocked with $1 \%$ bovine serum albumin (BSA) for $30 \mathrm{~min}$. Further, the cells were incubated with primary antibodies for anti-p-NF- $\mathrm{B} / \mathrm{p} 65$ Ser536, anti-rabbit-CD133 (Prominin 1), SMC2 and Cdk6 (rabbit IgG, Santa Cruz Biotechnology, Inc., Santa Cruz, CA, USA). All these antibodies were used at 1:200 dilutions. Subsequently, the cells were incubated with Alexa Fluor 488 (donkey anti-rabbit) secondary antibodies (both from Santa Cruz Biotechnology) for $1 \mathrm{~h}$ at room temperature in the dark. Cells were then washed with cold PBS and were counterstained with 4',6-diamidino-2-phenylindole (DAPI, Invitrogen). After incubation with DAPI for $5 \mathrm{~min}$ again cells were washed with cold $1 \mathrm{X}$ PBS. After addition of $1 \mathrm{ml}$ mounting media, cells were observed under a fluorescence microscope (Olympus, Milan, Italy) with adaptable filter consistent with Alexa Flour 488, FICT or PE.

Western blotting. Total proteins were isolated by ice-cold RIPA buffer PMSF (Sigma-Aldrich Corp., USA) and ready to use protein inhibitor cocktails (Fermentas, Thermo Scientific, Rockford, IL, USA). Protein concentrations were calculated by using Pierce ${ }^{\circledR}$ BCA Protein Assay kit (Thermo Scientific) following the manufacturer's instructions. Sixteen micrograms of protein were then loaded per well. Proteins were separated on $12 \%$ polyacrylamide gel and transferred to polyvinyline difluoride membranes (PVDF, Sigma-Aldrich Corp.) in the Bio-Rad western blotting system (Bio-Rad, Berkeley, CA, USA). The membrane was incubated with the primary antibodies $\beta$-actin (1:1,000), 1:200 diluted anti-p-NF- $\mathrm{B}$ antibody, anti-human-IL-6 antibody (rabbit IgG), Pro-apoptotic protein Casp- 8 was detected using 1:200 anti-casp- 8 antibody (rabbit IgG), Cdk6 (C-21) (rabbit IgG) and structural maintenance chromosomes protein-2 (SMC-2) (sc-10709 rabbit polyclonal IgG). All the antibodies used were procured from Santa Cruz Biotechnology. The proteins of interest were detected by an enhanced chemiluminescence detection kit following the manufacturer's instructions using LAS4000 machine (GE Healthcare).

Statistical analysis. After 6 days of injection tumors were visible. Each tumor was measured with Vernier calipers and the volume of the tumor $\left(\mathrm{mm}^{3}\right)$ was calculated by the following formula:

$$
\text { Volume }=(\text { width })^{2}\left(\frac{\text { length }}{2}\right)
$$

The size and the extent of metastasis of tumor under in vivo conditions was detected using LI-COR Pearl animal image analyzer (LI-COR Biosciences, USA). All the mice were sacrificed for the collection of the tumors.

The relative quantitative expressions of the genes by real-time qPCR and western blotting were analyzed by the analysis of variance (ANOVA). The significant differences between the mean expressions of different genes at $\mathrm{P}<0.05$ 
Table I. Primer sequence used in quantitative real-time PCR.

\begin{tabular}{|c|c|c|c|}
\hline Gene & Sequence & Melting temp. $\left(\mathrm{T}_{\mathrm{m}}{ }^{\circ} \mathrm{C}\right)$ & Accession no. \\
\hline$\beta$-actin & $\begin{array}{l}\text { F-GGACTTCGAGCAAGAGATGG } \\
\text { R-AGCACTGTGTTGGCGTACAG }\end{array}$ & 57.50 & NM_001101 \\
\hline Cdk6 & $\begin{array}{l}\text { F-AGAGACAGGAGTGGCCTTGA } \\
\text { R-TGAAAGCAAGCAAACAGGTG }\end{array}$ & 55.40 & NM_001145306 \\
\hline$N F-\kappa B(p 65)$ & $\begin{array}{l}\text { F-CTGAACCAGGGCATACCTGT } \\
\text { R-GAGAAGTCCATGTCCGCAAT }\end{array}$ & 56.45 & NM_001243984 \\
\hline$I L-6$ & $\begin{array}{l}\text { F-TACCCCCAGGAGAAGATTCC } \\
\text { R-TTTTCTGCCAGTGCCTCTTT }\end{array}$ & 55.45 & NM_000600.3 \\
\hline Casp-8 & $\begin{array}{l}\text { F-TATGGCACTGATGGACAGGA } \\
\text { R-GCAGAAAGTCAGCCTCATCC }\end{array}$ & 54.40 & NM_001228 \\
\hline$S M C 2$ & $\begin{array}{l}\text { F-CACCACCAGAGGGTCAAACT } \\
\text { R-TGAGTACGCAGCATCTGTCC }\end{array}$ & 57.50 & NM_001042551 \\
\hline Oct4 & $\begin{array}{l}\text { F-TATGGGAGCCCTCACTTCAC } \\
\text { R-CAAAAACCCTGGCACAAACT }\end{array}$ & 57.50 & NM_002701 \\
\hline Promininl (CD133) & $\begin{array}{l}\text { F-GCCAGCCTCAGACAGAAAAC } \\
\text { R-CCAAGCCTTAGGAGCATCTG }\end{array}$ & 57.50 & NM_001145848 \\
\hline$I \kappa B \alpha$ & $\begin{array}{l}\text { F-TTGGGTGCTGATGTCAATGC } \\
\text { R-CTCACTCTCTGGCAGCATCT }\end{array}$ & 56.45 & NM_020529 \\
\hline
\end{tabular}

were analyzed by Tukey's b-test. The values are expressed as mean $\pm \mathrm{SEM}$.

\section{Results}

Promonin 1 is a novel SLCIC marker in various carcinomas involved in tumorigenesis with MDR. In an attempt to identify SLCICs, CD133 expressing Cal72 cells were analyzed. The cells were characterized on the basis of expression of $\mathrm{CD} 133^{+}$ on their cell surface, as found in number of malignancies. To verify the $\mathrm{CD} 133^{+}$as an SLCIC marker, cells were stained with monoclonal antibody human anti-CD133-FITC with isocontrol and showed overexpression in Cal72 cells (Fig. 1A). Similarly, Oct4 with higher invasiveness and proliferative rate was overexpressed in immunocytochemistry of SLCICs in tumor sphere assay in vitro. Formation of tumor spheroids of high grade was also confirmed by the Oct4 expression in SLCICs in vitro (Fig. 1B) and in vivo (Fig. 1C). Moreover, the $\mathrm{CD}_{133^{+}}$expressed on the cell surface of cancer cells (Fig. 1A) can proliferate and metastasize in in vivo. Palpable tumors were visible after 7 days of injection and to endorse the tumorigenesis capability of CD133 ${ }^{+}$expressing SLCICs, the tumors were visualized by LI-COR Biosciences Pearl impulse IR-fluorophore, IRDye ${ }^{\circledR} 800 \mathrm{CW} 2$-deoxyglucose optical imaging system. In this approach the size, grade as well as the metastasis of the tumor were distinctly observed (Fig. 1C). In contrast, the SLCICs are often characterized by a high metabolic rate exemplified by a dramatically elevated glucose uptake. The IRDye $800 \mathrm{CW} 2 \mathrm{DG}$ was used for its ability to target several different tumor types for example solid tumors, colon tumors and soft tumors. This biological activity has been exploited by non-invasive imaging system using infrared pseudo-colored fluorescent signals. Further, pseudocolored fluorescent signals were superimposed on a white light image using glucose analogues such as ${ }^{18} \mathrm{~F}$-2-deoxy-D-glucose (due to high glucose metabolism in tumor sites) to generate a tumor-localized signal (Fig. 1C). Higher intensity signals are in red, while lower signal intensity is in blue (Fig. 1C). For more valid confirmation, cells from solid subcutaneous tumor and CD133 expressing SLCICs were stained with anti-human CD133-FITC conjugate after one day of their isolation and were further assessed by FACS. The CD133+ ${ }^{+}$rich SLCICs were selected according to forward scatter (FSC) and side scatter (SSC) property using the gated region $\mathrm{R} 4$ to remove the cell debris, residual platelets and red cell contamination. FACS analysis showed the presence of a variable fraction of $\mathrm{CD} 133^{+}$ cell populations in tumor-bearing nude mouse samples, 18.31 and $48.22 \%$, respectively. However, 2.05 and $16.12 \% \mathrm{CD} 133^{+}$ were observed in Cal72 SLCICs. (Fig. 1D). Moreover, these SLCICs are $\mathrm{CD}_{133^{+}}$rich tumor initiating populations which can be characterized by flow cytometry. A significant $(\mathrm{P}<0.05)$ quantitative transcript level of CD133 in both Cal72 $(0.87 \%)$ and SaOS-2 (0.79\%) SLCICs, respectively, was analyzed by qPCR (Fig. 1E).

BRM270 does not affect normal human cells while it suppresses the stemness to induce mitotic DNA damage catastrophe and $G 1 \rightarrow S / G 2 M$ transition during premature apoptosis. Cell cycle progression is highly regulated at several checkpoints to ensure proper DNA synthesis and 

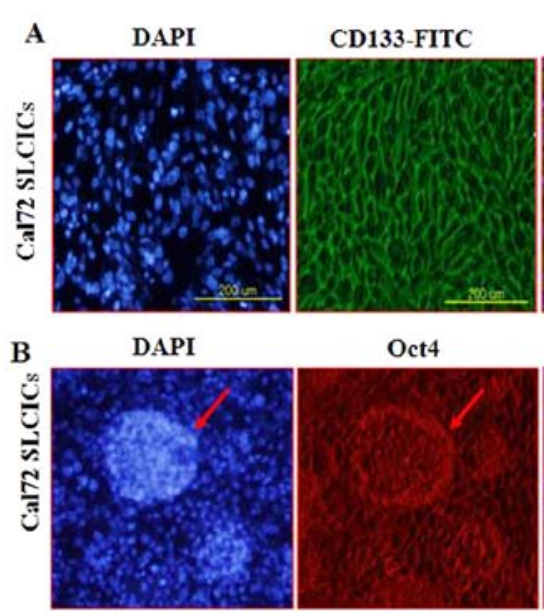

Oct4

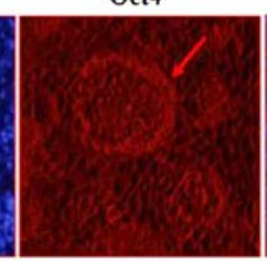

C

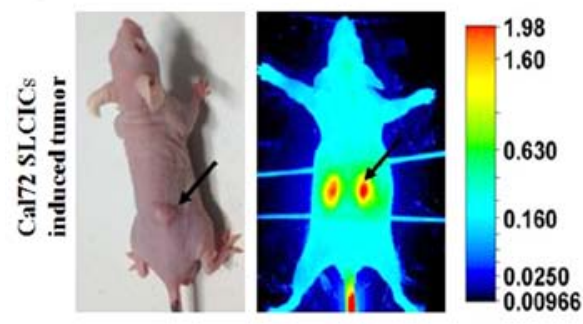

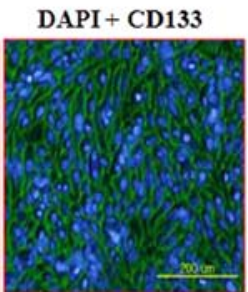

Merged
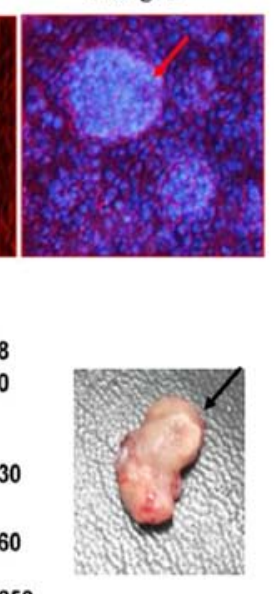
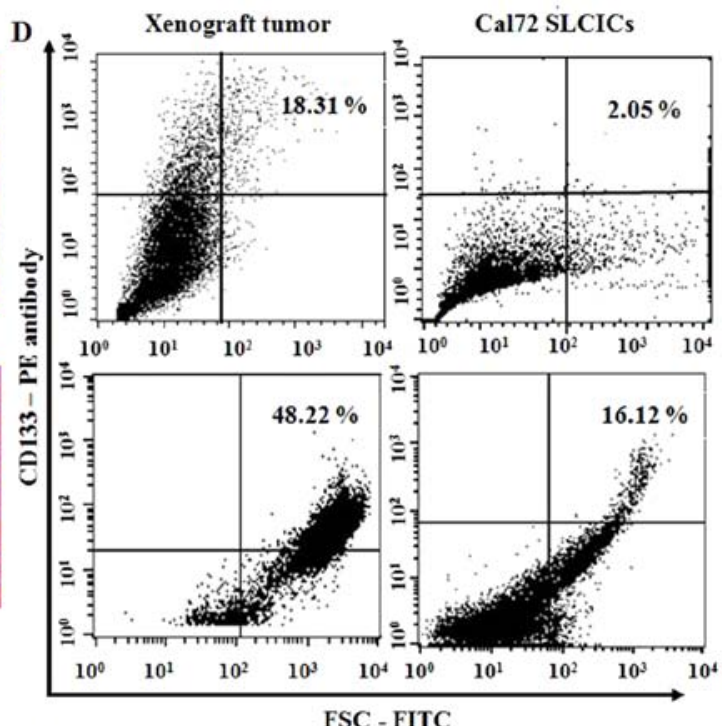

$\mathbf{E}$

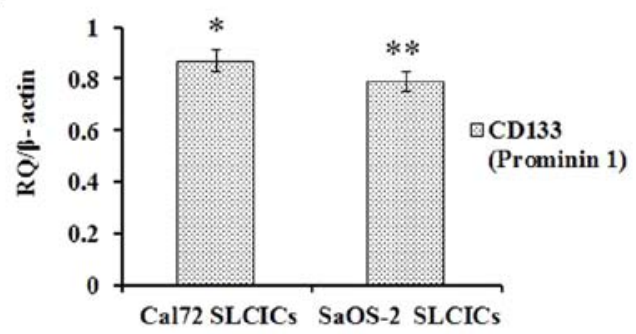

Figure 1. CD133 is a novel biomarker of SLCICs in tumorigenesis with multidrug resistance (MDR). (A) Immunocytochemistry of Cal72 SLCICs exert the overexpression of CD133, blue staining shows nuclear DAPI, CD133 is overexpressed in green followed by their merged expression. (B) In vitro immunocytochemistry-based tumor sphere forming assay showing the overexpression of Oct3/4 in CD133 expressing Cal72 SLCICs. (C) CD133 expressing Cal72 cells are efficient in inducing tumors in BALC nude mouse and showed high grade of tumor using LI-COR Pearl image analyzer. (D) To characterize the CD133 expressing Cal72 SLCICs were stained with CD133-FITC and analyzed by flow cytometry showing CD133 rich subpopulation in gated region. (E) Quantitative expression of CD133 in both SaOS-2 and Cal72 SLCICs by qPCR. The data are expressed as mean $\pm \mathrm{SEM}\left({ }^{*} \mathrm{P}<0.05\right)$.

chromosome segregation. It has become increasingly clear that the deregulation of CDK pathways causes unscheduled proliferation that contributes to oncogenic transformation. In the present study, we showed that efficacy of BRM270 against Dox-resistant SLCICs in a dose- and time-dependent manner induced morphological cell shrinkage of DNA and apoptosis (Fig. 2A and B). BRM270 selectively inhibits cell proliferation by inducing programmed cell death (PCD) and mitotic cell death (MCD) due to unrepaired DNA damage during premature apoptosis (Fig. 2B and F). Initially the morphology of chromatin condensed in the cultured cells undergoing apoptosis was compared with that of in vitro triggered DNA fragmentation in nuclei isolated from the corresponding non-apoptotic cells (Fig. 2B and F). Therefore after $24 \mathrm{~h}$ of exposure, cells treated with BRM270 and Dox in a dosedependent manner, were observed for DNA fragmentation and chromatin condensation by confocal fluorescence microscope (Fig. 2A and B). Further, the genomic DNA was extracted and was separated on $1.2 \%$ agarose gel. To confirm the extent of genomic DNA fragmentation by BRM270, the DNA was run in the gel stained with ethidium bromide $(\mathrm{EtBr})$ and was visualized under UV light (Fig. 2F). It showed that hallmark of apoptotic cell death is the cleavage of chromosomal DNA at inter-nucleosomal sites into fragments of multiples sizes (Fig. 2B and F). For confirmation of DNA damage-induced mitotic cell death, $\mathrm{CD}_{133^{+}}$expressing SLCICs treated with BRM270 and Dox, were stained with Hoechst 33258. It was observed that BRM270 interrupts the microtubule cytoskeletal formation in Dox resistant SLCICs, formed chromosomal condensation (pyknosis), nuclear fragmentation (karyorrhexis) (Fig. 2B, 5 and 6, red arrows) and cytoplasmic shrinkage (Fig. 2B, 2 and 5, yellow arrows). BRM270 displayed potent cytotoxicity in Dox resistant SLCICs by changed morphology of cells (Fig. 2A, 2 and 5). In addition, BRM270 shows selective inhibition of the neoplasm. Cytotoxicity was analyzed by clorometric assay 3-(4,5-dimethylthiazol-2-yl)-2, 5-diphenyltetrazolium bromide (MTT assay) (Fig. 2C) where it showed its ability to kill the $\mathrm{CD}_{133^{+}}$expressing SLCICs. MTT assay analysis showed that at the concentration of $125 \mu \mathrm{g} / \mathrm{ml}$, after $24 \mathrm{~h}$ exposure with BRM270, 4.51\% (CD133 ${ }^{+}$expressing Cal 72 SLCICs) and $7.253 \%$ (SaOS-2 SLCICs) viability was recorded. Further, to evaluate the cytotoxic effect of BRM270 on a normal human cell line, hBMCs were used. At the similar conditions as those of cancer cell lines, hBMCs showed $93.41 \%$ viability with respect to control (Fig. 2A, 7-9 and C). Similarly, in Dox treated group 17.95, 13.56 and $79.99 \%$ viability was observed in Cal72, SaOS-2 and hBMCs, respectively (Fig. 2D). It showed that Dox is more toxic in normal cells compare with BRM270 (Fig. 2C and D). Furthermore, $\mathrm{CD}_{133^{+}}$and Oct3/4 in Cal72 SLCICs have indicated stemness while after treat- 

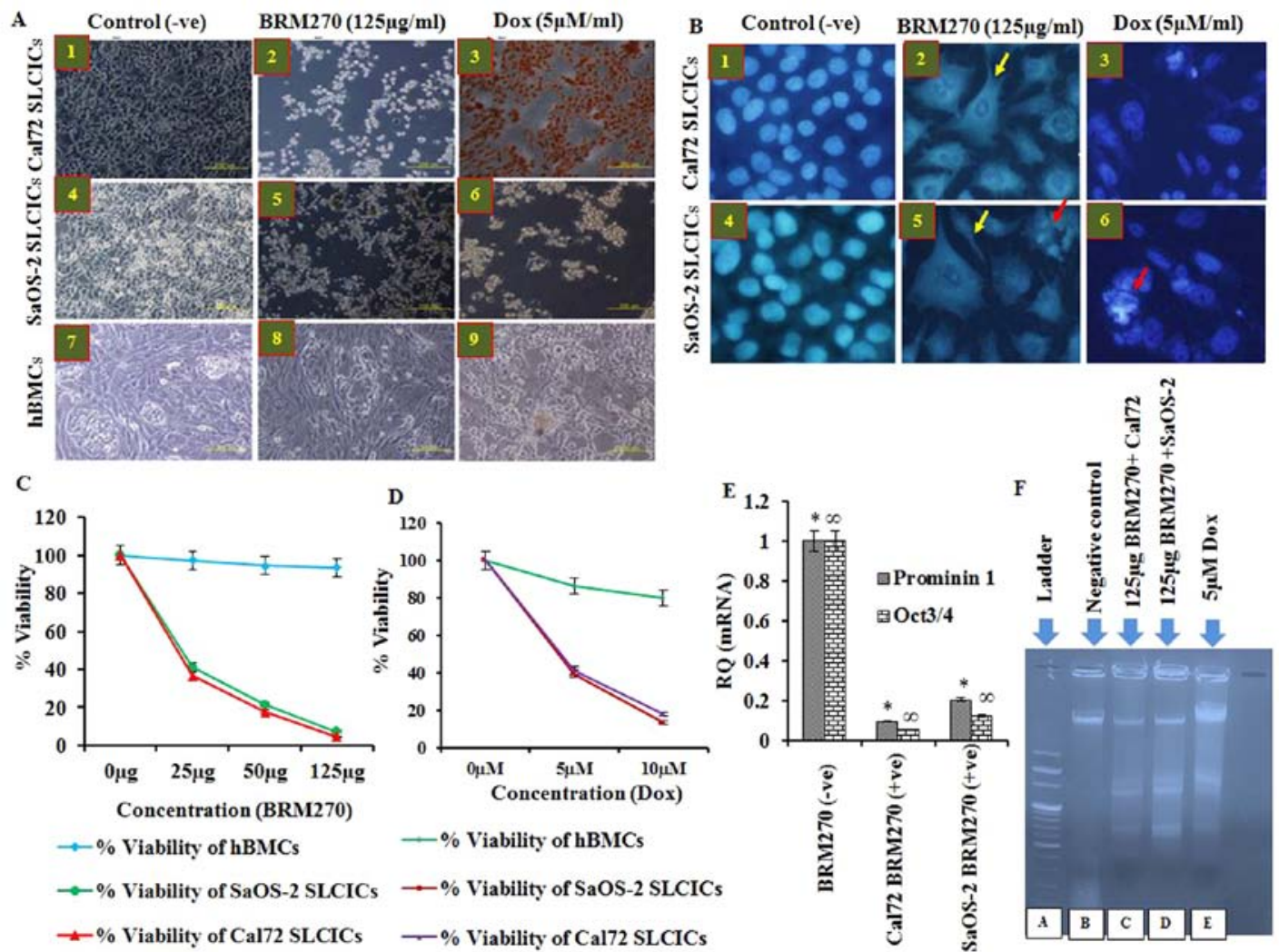

Figure 2. BRM270 does not affect normal human cells while it suppresses the stemness to induce mitotic DNA damage catastrophe, DNA condensation and shrinkage and is highly cytotoxic on SLCICs. (A) Morphological changes of CD133 expressing SLCICs were observed under phase-contrast inverted microscope with untreated SLCICs and hBMCs were treated with $125 \mu \mathrm{g} / \mathrm{ml}$ concentration of BRM270 while $5 \mu \mathrm{M} / \mathrm{ml}$ Dox was treated as a positive control for $24 \mathrm{~h}$. (B) Confirmation of the DNA fragmentation apoptosis, condensation and shrinkage of cells with Hoechst 33342 staining (blue DNA). The untreated Cal72 SLCICs normal looking flat oval-shaped nuclei that are uniformly blue; the nuclei of early apoptotic cells show several lobular or fragmented blue bodies, catastrophe and shrinkage (yellow arrow). The nuclei of late apoptotic cells contain several fragmented white-blue bodies (red arrow); and necrotic cells contain light blue nuclei that are round or oval in shape. (C) Confirmation of cytotoxicity of BRM270 as a novel inhibitor of neoplasia was confirmed by cell viability test (MTT assay) in CD133 expressing Cal72 in a dose-dependent manner. (D) Higher toxicity of Dox in neoplasia was confirmed by MTT assay in CD133 where it also confirmed its high cytotoxicity in normal cells with respect to BRM270. (E) Relative qPCR analysis of CD133 and Oct4 gene expression in Cal72 SLCICs treated with BRM270 in both Cal72 and SaOS-2 SLCICs. (F) Genomic DNA fragmentation of Cal72 SLCICs exposed to BRM270 with different concentration for 24-h exposure. DNA laddering formation was viewed on ethidium bromide-stained gel $(1.2 \%)$. The data are mean \pm SEM $(* \mathrm{P}<0.05)$.
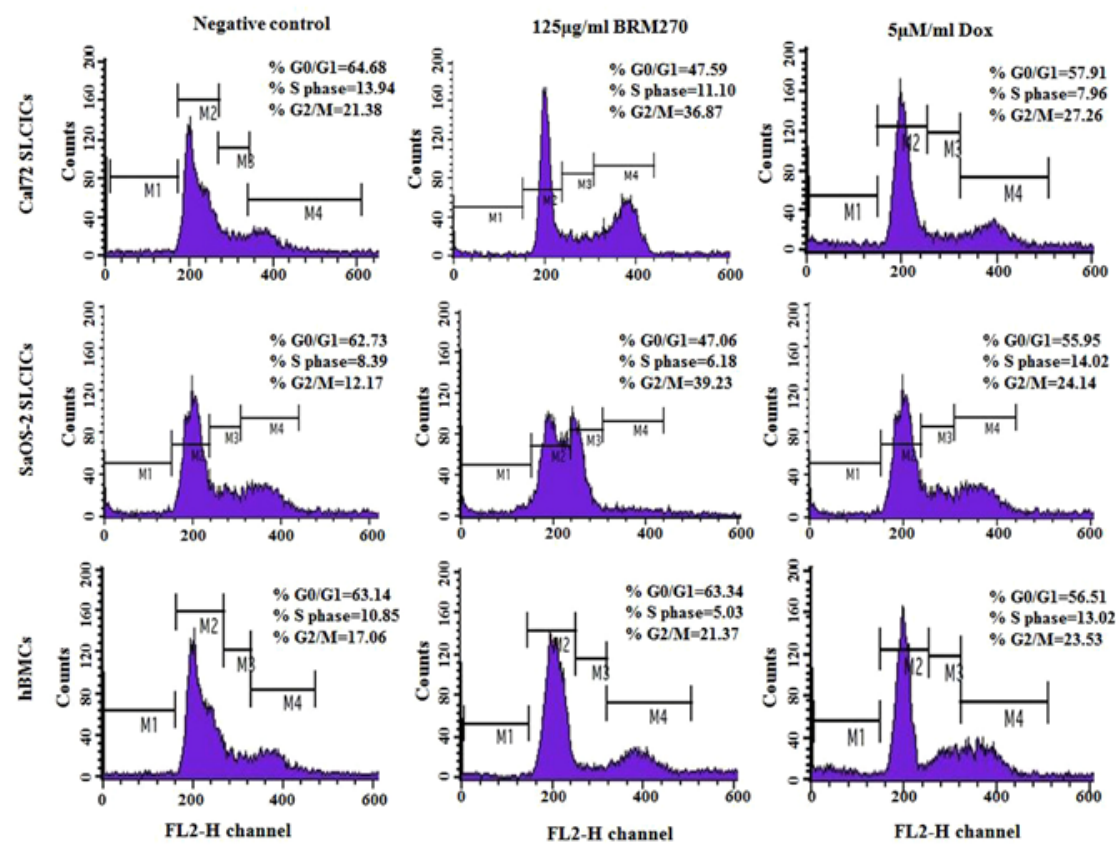

Figure 3. Influence of BRM270 on cell cycle progression/distribution in stem SLCICs and normal hBMCs. Cell cycle analysis of Cal72 SLCICs, SaOS-2 and normal hBMCs after being cultured with BRM270 for $24 \mathrm{~h}$, BRM270 induced an increase in G2/M phase cells (\%). The data are mean \pm SEM ("P<0.05). 

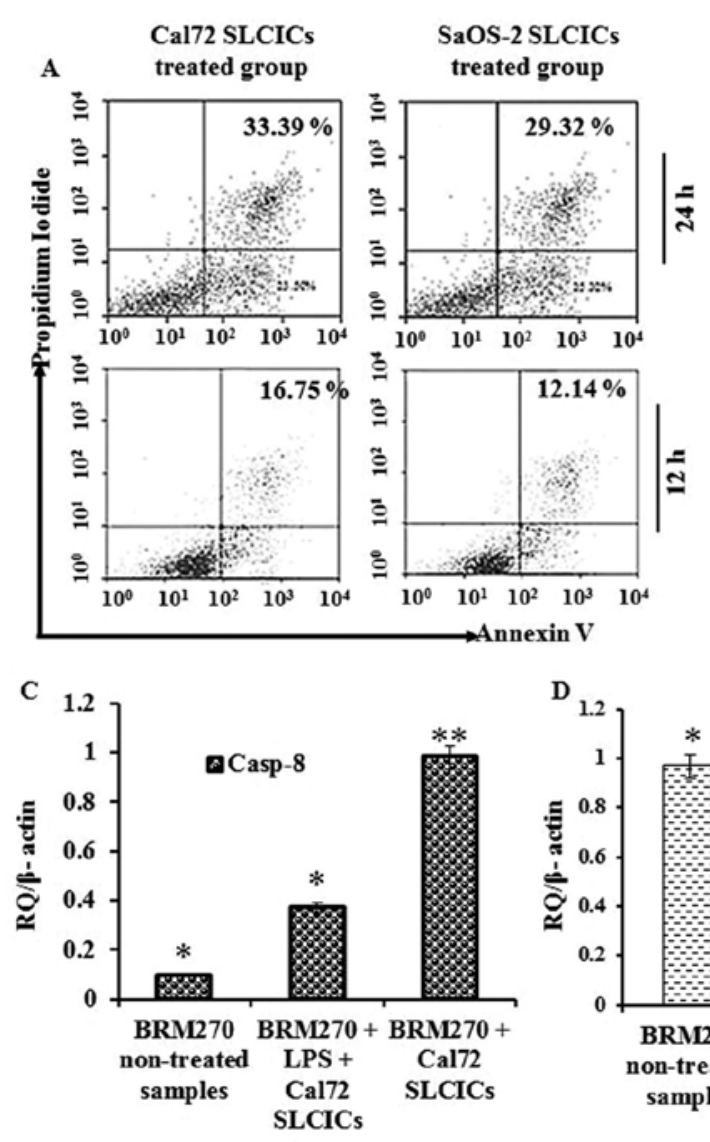

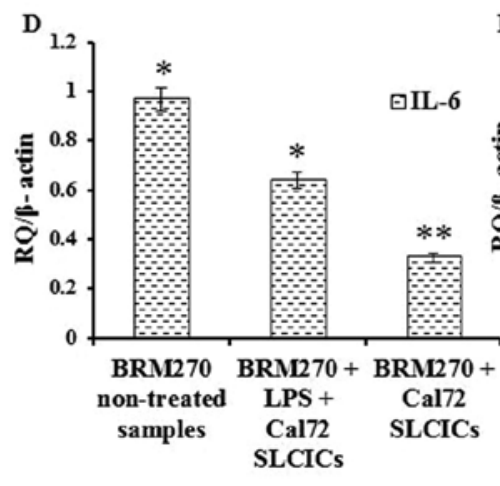

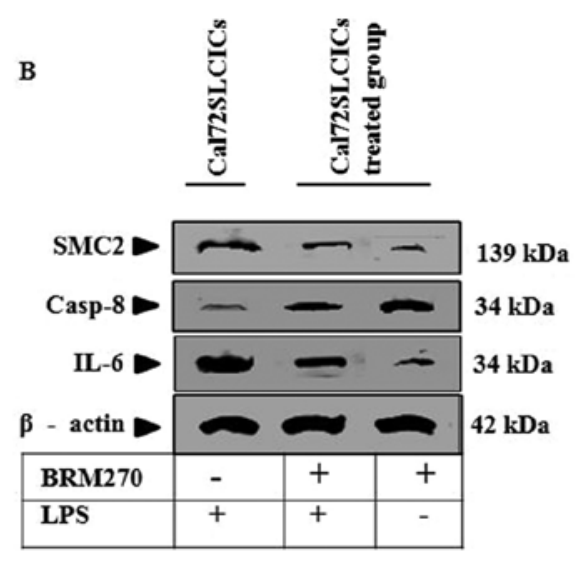

$\mathbf{E}$

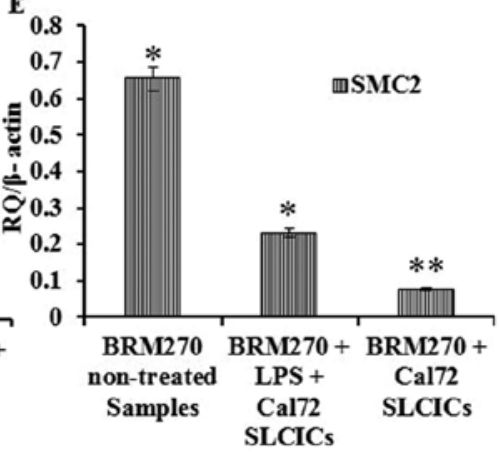

Figure 4. BRM270 induces IL-6 mediated apoptosis in CD133+ Cal72 SLCICs via downregulation of chromatin SMC2. Cells were incubated for 24 h with BRM270. (A) Apoptotic cell death was measured by flow-assisted cytometry analysis with fluorescein isothiocyanate-conjugated Annexin V/PI staining at $24 \mathrm{~h}$ after BRM270 to determine phytodrug-induced apoptosis in Cal72 SLCICs and SaOS-2 SLCICs. The lower right quadrant indicates early apoptotic cells. The early apoptotic cells are presented by a quantitative analysis. (B) Protein lysates were analyzed by western blot analysis using IL-6 mediated regulation of anti-apoptosis gene Casp-8 and chromatin structure condensing gene SMC2 (Condensin-2) antibodies in Cal72 SLCICs with LPS or without LPS at 24 h after BRM270 exposure. (C) Significant expression of Casp-8 increased after exposure of BRM270 treated Cal72 SLCICs than LPS with BRM270 treated group. (D) Simultaneous decrease in IL-6 expression in BRM270 and LPS with BRM270 groups. (E) Expression of the chromatin structure forming gene SMC2 is more downregulated in BRM270 treated group with respect to LPS with BRM270 in Cal72 SLCICs. The data are mean \pm SEM (*P<0.05).

ment with BRM270 a significant $(\mathrm{P}<0.05)$ decrease in their levels was found (Fig. 2E). The cell cycle progression in both parental and Dox-resistant SLCICs after $24 \mathrm{~h}$ exposure of BRM270 was observed (Fig. 2A, 2 and 5). Flow cytometry analysis showed a significant $(\mathrm{P}<0.05)$ decrease in cell population from G0-G1 phases (Fig. 3). A significant decrease (17.09\%) was recorded in the Cal72-SLCICs population after their treatment with BRM270 as compared to $6.77 \%$ decrease in the cell population after their exposure to Dox. The $15.49 \%$ (BRM270 treated) and $5.88 \%$ (Dox treated) concomitant accumulation or transit of cells in the G2/M checkpoint (BRM270-15.49\%, Dox-5.88\%) was recorded in $\mathrm{CD}_{133^{+}}$expressing Cal72 SLCICs. Again, SaOS-2 SLCIC cell samples were collected and the cells were stained with propidium iodide to analyze cell cycle arrest which divulged transition from G0-G1 (loss 4.82\%) into G2/M phase (transit $15.09 \%$ ) while in normal hBMCs, checkpoints for transition of $\mathrm{G} 2 / \mathrm{M}$ are $\mathrm{G} 0-\mathrm{G} 1$ (loss $0.2 \%$ ) into $\mathrm{G} 2 / \mathrm{M}$ phase (transit $4.31 \%$ ) while in Dox treated G0-G1 (loss 6.63\%) to G2/M $(6.47 \%)$, respectively (Fig. 3). This finding suggests that the anticancer drug Dox arrests cells at G0. Further it was also observed that transit to $\mathrm{G} 2 / \mathrm{M}$ checkpoint by Dox is less than the NF- $\kappa$ B novel inhibitor BRM270 in both SaOS-2 and Cal72 SLCICs while Dox showed more cytotoxicity to normal hBMCs compared to BRM270.

BRM270 induces IL- 6 mediated apoptosis in $\mathrm{CD} 133^{+}$SLCICs via downregulation of SMC2. BRM270 induced IL-6 mediated apoptosis and the expression of pro-apoptotic proteins was observed in SLCICs. Apoptotic cell death was measured with fluorescein isothiocyanate-conjugated Annexin V and PI staining at 12 and $24 \mathrm{~h}$ after treated with BRM270. Apoptosis induced by BRM270 was studied in Cal72 SLCICs and SaOS-2 SLCICs. The lower right quadrant in Fig. 4A indicates early apoptotic cells. In addition, the number of apoptotic cells (Annexin V-positive cells) increased in both CD133+ expressing Cal72 and SaOS-2 SLCICs after 24-h exposure to BRM270. The Annexin V-FITC assay showed that $\sim 16.75$ and $12.14 \%$ in $12 \mathrm{~h}$, while 33.39 and $29.32 \%$ in $24 \mathrm{~h}$ underwent apoptosis with the exposure to BRM270 in both Cal72 and SaOS-2 SLCICs, respectively. No significant $(\mathrm{P}<0.05)$ difference in the necrotic cells (PI-positive and Annexin V-negative cells) was observed between the groups (Fig. 4A). On the basis of time of exposure to BRM270 in 
$\mathbf{A}$

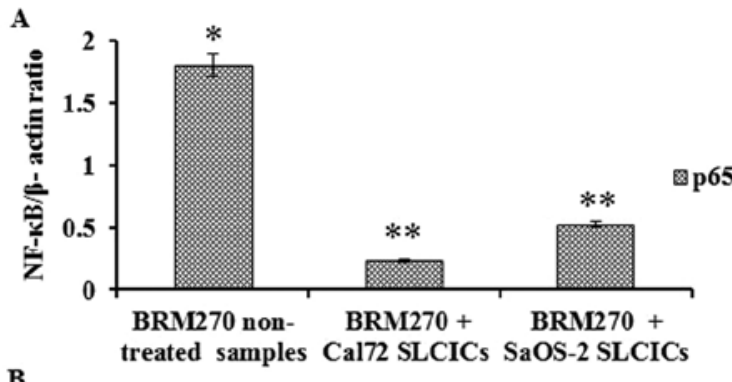

B

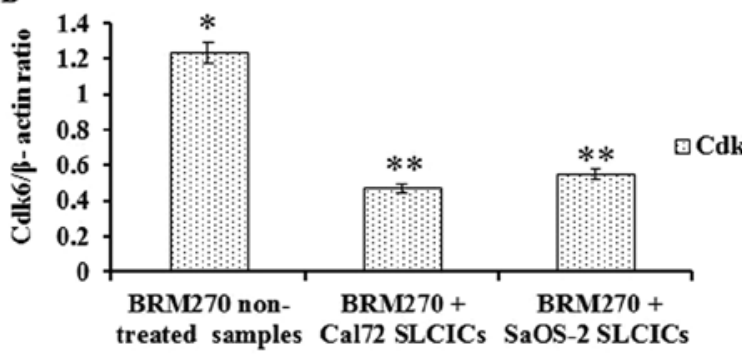

C

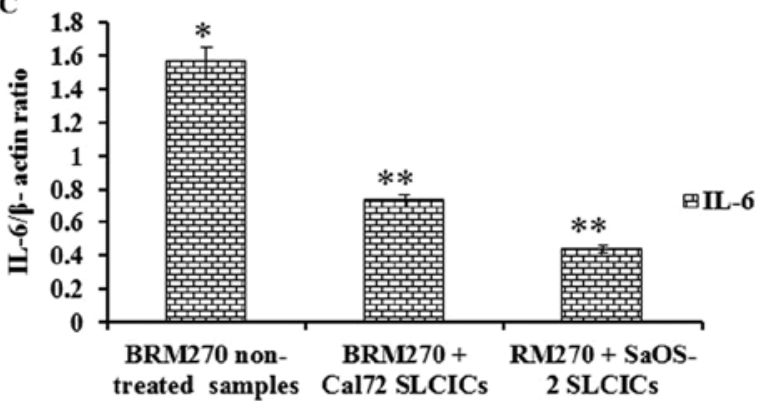

D
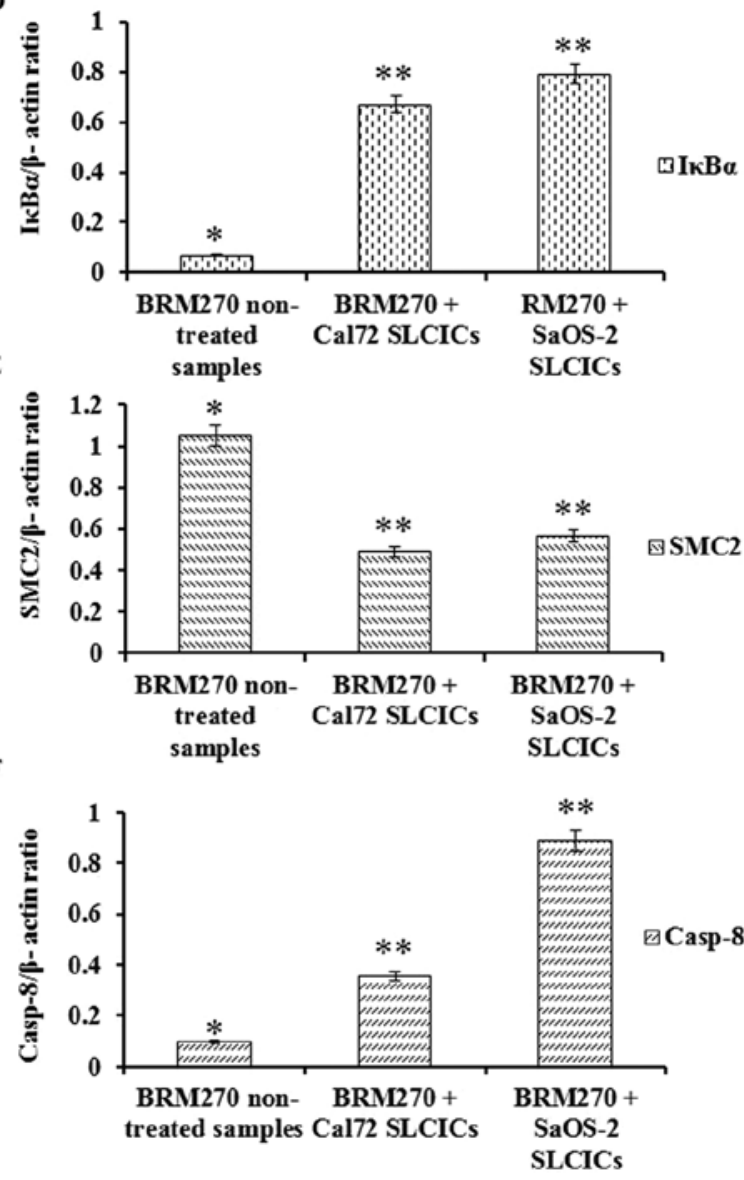

Figure 5. IL-6 augments the neoplasia chemotherapeutic drug-resistance ameliorated via co-suppression of p65 and Cdk6 by BRM270 in SLCICs. Quantitative transcripts of Cal72 SLCICs with LPS and without LPS after treatment with BRM270. (A) Relative transcript levels of NF- $\mathrm{kB}$-related genes in Cal72 SLCICs. (B) Relative expression of Cdk6 in Cal72 SLCICs. (C) Expression of pro-inflammatory cytokine-related genes; IL-6 in Cal72 SLCICs. (D) Quantitative expression of IкB $\alpha$ in Cal72 SLCICs. (E) Expression of SMC2 in Cal72 SLCICs. (F) Expression of Casp-8 in Cal72 SLCICs. The data are mean $\pm \operatorname{SEM}\left({ }^{*} \mathrm{P}<0.05\right)$.

both cell lines, significant differences were observed. The number of early apoptotic cells (Annexin V-positive and PI-negative cells) was $\sim 2$-fold greater in both cell lines at $24 \mathrm{~h}$ exposure than the $12 \mathrm{~h}$ of exposure (Fig. 4A). Furthermore, protein lysates were analyzed by western blotting using IL-6-mediated regulation of pro-apoptosis protein Casp-8 and SMC2 in Cal72 SLCICs (Fig. 4B-E). Similarly, qPCR revealed the relative quantitatively downregulated levels of IL-6 and SMC2 whereas increased transcript levels of Casp-8 were observed in both Cal72 SLCICs and SaOS-2 SLCICs (Fig. 5C, E and F). These results suggest that downregulation of IL-6 and SMC2 increased Casp- 8 activity and enhanced BRM270-induced apoptosis in CD133 expressing Cal72 and SaOS-2 SLCICs. To demonstrate the direct effects of BRM270 to regulate NF- $\mathrm{KB}$ signal trafficking, before exposure to BRM270 the cells were given treatment with LPS. Later, the blot expressions of Casp- 8 and SMC2 was studied in the cells treated with and without LPS after $24 \mathrm{~h}$ exposure to BRM270. However, there is significant difference $(\mathrm{P}<0.05)$ in the blot expression of both BRM270 with LPS and only BRM270 treated groups (Fig. 4B). Moreover, the relative transcriptomic levels of apoptotic gene Casp-8 increased more significantly $(\mathrm{P}<0.05)$ in Cal72 SLCICs than
LPS treated group after treatment with BRK270. At the same time, a significant $(\mathrm{P}<0.05)$ decrease in the transcriptomic levels of IL-6 were recorded in both groups. Moreover, a significant decrease in the transcript levels of SMC2 was recorded in the group without treatment with LPS as compare to cell lines treated with LPS after exposure to BRM270 (Fig. 4B, C and E).

IL- 6 augments the neoplasia chemotherapeutic drugresistance ameliorated via co-suppression of p65 and Cdk6 by BRM270 in SLCICs: as a mechanistic approach. The relationships between the level of IL-6 with the expression of Cdk6, NF-kB and Casp-8 in CD133 expressing Cal72 SLCICs were investigated (Figs. 5 and 6) to understand the role of IL-6 in crosstalk between NF- $\mathrm{kB}$ signaling cascades in SLCICs mediated cancer progression and MDR. On comparison of the transcriptional levels of candidate genes after BRM270 treatment with respect to NC, the Cdk6 showed significantly higher transcript levels in Cal72 SLCICs than the BRM270 treated group (Fig. 5B). Similarly, NF- $\kappa$ B was also overexpressed in non-BRM270 treated SLCICs while after treatment it was suppressed simultaneously with Cdk6 (Figs. 5A, B and 6F). Further, to investigate the effect 


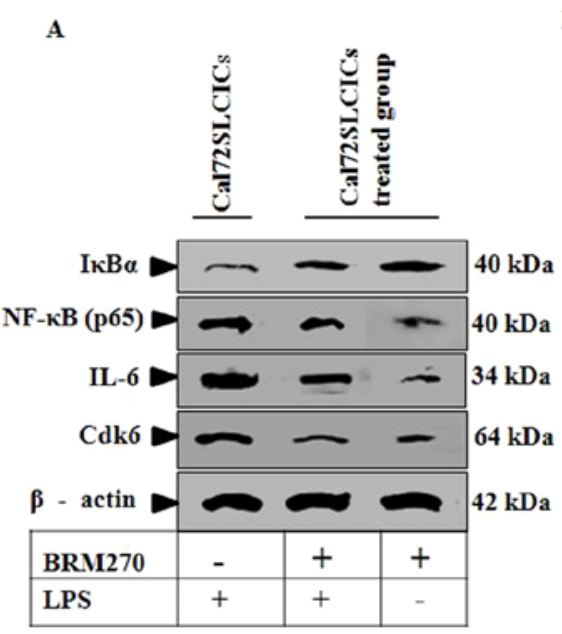

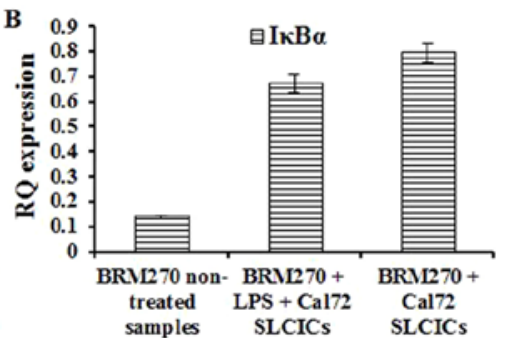

C

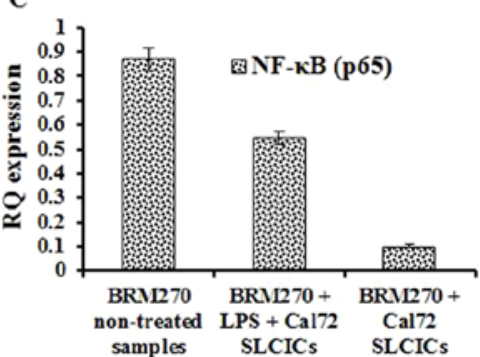

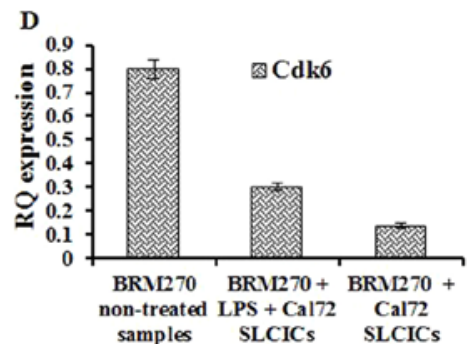

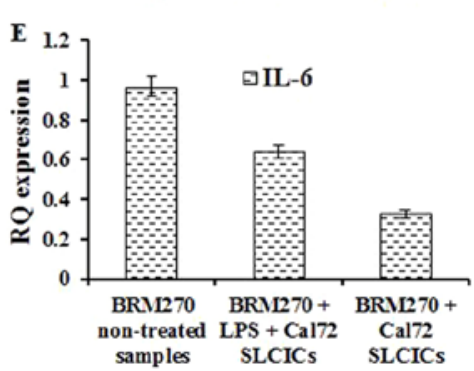

F BRM270 non-treated
p65 and Cdk6

BRM270 treated

BRM270 treated
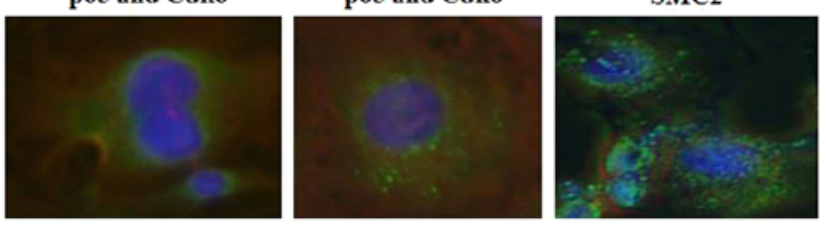

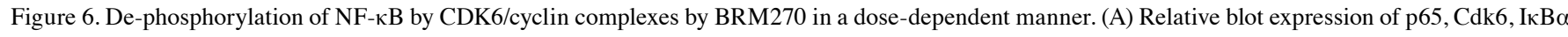
and IL- 6 after their normalization with blot expression of $\beta$-actin under the influence of BRM270. (B) Relative quantitative expression of IкB $\alpha$ observed in Ca172 SLCICs. (C) Relative quantitative expression of p65 observed in Cal72 SLCICs. (D) Relative quantitative expression of Cdk6 observed in Cal72 SLCICs. (E) Relative quantitatively expression of IL-6 observed in Cal72 SLCICs. (F) Co-localization of p65 (NF-kB) with Cdk6 and SMC2 in Cal72 SLCICs in BRM270 non-treated and treated with LPS and without LPS. The data are mean \pm SEM $(\mathrm{P}<0.05)$.

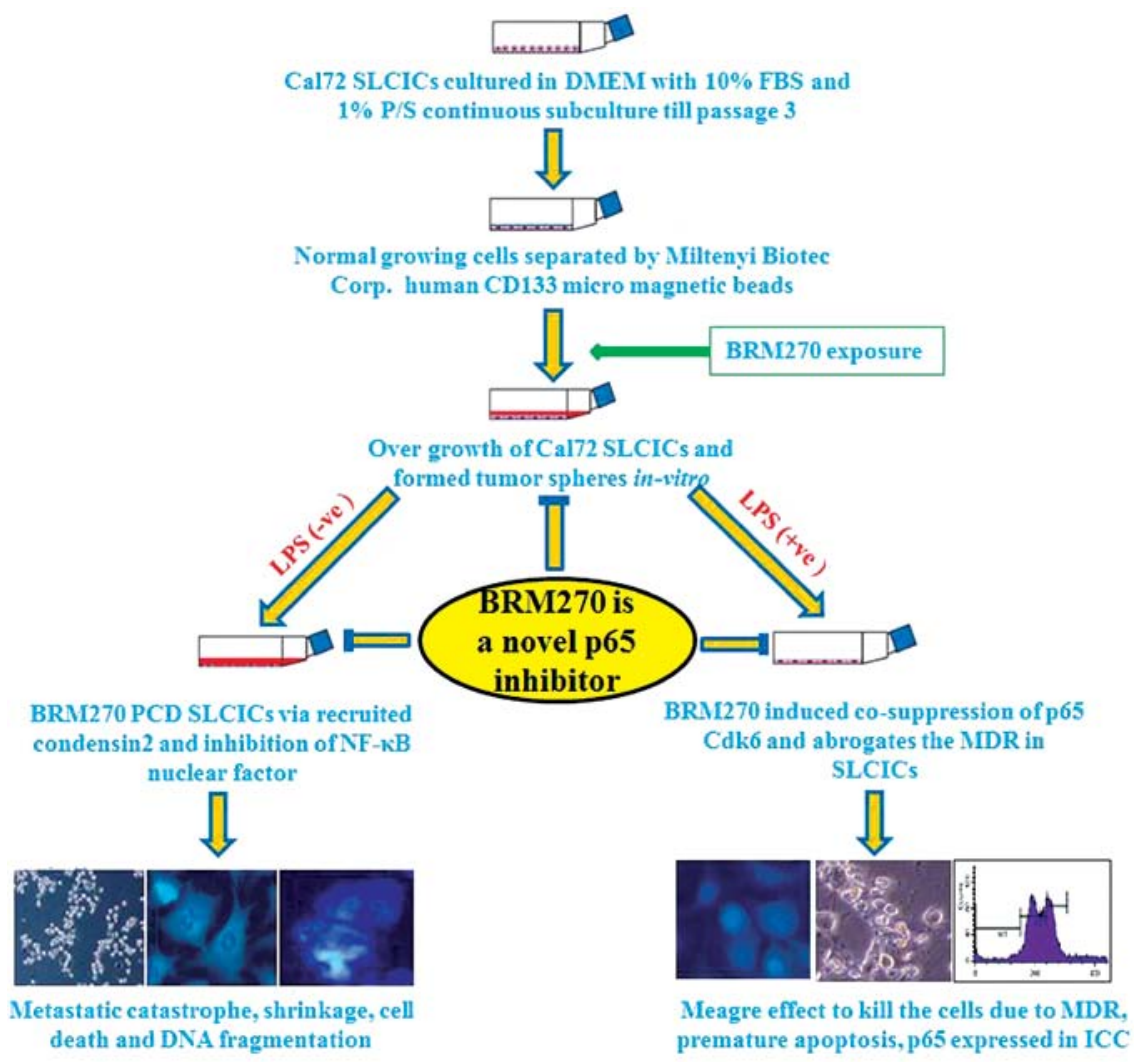

Figure 7. Representation of BRM270 as a novel inhibitor, and the NF- $\mathrm{kB}$ signaling cascade, regulation and amelioration of cancer progression by targeting the Cdk6 and p65 under the influence of BRM270. 
of BRM270 we targeted the IL-6 induced NF- $\kappa$ B activation pathway. IL-6 is reported to enhance the stemness of the oncogenic cells when demonstrating the MDR to Dox. An attempt was made to find the efficacy of BRM270 on SLCICs in a dose-dependent manner (Figs. 1E and 2D). Although, it recruits the Cdk6 to catalyze the cyclin-D which upregulates the cell cycle in G0/G1 phase (Fig. 3) in cancer stem cells. It has been observed that $\mathrm{CD}_{133^{+}}$SLCICs induces tumorigenesis via $\mathrm{NF}-\kappa \mathrm{B}$ signaling where Cdk6 is co-localized with p65 (Fig. 6F). Moreover, qPCR analysis has demonstrated the efficacy of BRM270 which suppressed the expression of p65 and Cdk6 significantly $(\mathrm{P}<0.05)$ in vitro (Fig. 5A and B). It further arrests the cell cycle at G1 phase and transit to G2/M phase (Fig. 3). In the LPS treated group IL-6 overexpressed the stemness property of $\mathrm{CD} 133^{+}$SLCICs (Figs. 2E and $6 \mathrm{E})$. It also exerted MDR under in vitro conditions (Fig. 2A-C). On the contrary, non-LPS treated group demonstrated higher cytotoxicity, which in turn led to decrease in the proliferation rate and viability of the SLCICs in Dox and BRM270 treated groups (Fig. 2A-C). Significantly higher blot expression of I $\mathrm{B} \alpha$, p 65 and IL-6 was observed towards the enhanced tumorigenicity under in vivo and in vitro conditions (Figs. 2A-C and 6A). On treatment with BRM270 in the SLCICs and in the nude mouse model, in vitro and in vivo conditions, a dramatically downregulated expression of $\mathrm{NF}-\kappa \mathrm{B}$ was observed. Findings from $\mathrm{qPCR}$ and western blotting also supported the concept of co-suppression of Cdk6 and p65 (Figs. 2A-C, 5A-C and 6A and F).

\section{Discussion}

Understanding the biological underpinning of SLCIC-induced tumor progression such as in subcutaneous osteosarcoma and hepatocarcinoma are keys for advances in therapy. Aberrant expression of IL-6, NF- $\mathrm{B}$ B with Cdk6 is found in many cancers $(12,20)$. Studies of the functional role of BRM270 as tumor suppressor can identify new pathways in cancers (15-17). It provides insight into the development of new or adjuvant therapies. First, we conducted a sphere-forming assay to confirm whether CD133 expressing Cal72 SLCICs have the stemness characteristics of CSCs (Fig. 2B and D). The cancer stem cell hypothesis suggests that SLCICs are tumorigenic cells which contain intra-tumoral heterogeneity $(1,21)$. Systemic metastasis and treatment failure are often associated with the survival of a small number of cancer cells $(2,21)$. To define the wide range of efficacy of BRM270 as an inhibitor of $\mathrm{NF}-\kappa \mathrm{B}$ signaling cascade, its effective role in two cancer stem cell lines expressing CD133+ i.e., Cal72 and SaOS-2 SLCICs were studied. Furthermore, the cytotoxic effect of BRM270 in the normal hBMC line was also studied. The SLCICs are enriched with CD133 protein on the cell surface which adhere to anti-human CD133 magnetic MicroBeads, during their separation in the higher magnetic field (separator) (22). To have better understanding of SLCICs and their role in the cancer progression, an increased population of CD133 SLCICs induced primary tumor in a prospectively collected series of osteosarcoma cancer-bearing nude mouse samples were analyzed in the present study (Fig. 1B and C). Similarly, Bertolini et al (23) and Peickert et al (24) reported that CD133+ subpopulation is efficiently tumorigenic in nude mouse with respect to CD133 SLCICs. Immunocytochemistry was used to elucidate the expression of CD133 in vitro which demonstrated the overexpression. Shmelkov et al (25) reported that both $\mathrm{CD}_{133^{+}}$and $\mathrm{CD}_{133^{-}}$metastatic tumor subpopulations formed colony spheres in in vitro cultures and were capable of long-term tumorigenesis in a NOD/SCID mouse. Similarly, our findings by immunocytochemistry (ICC) revealed that the CD133 overexpressing SLCICs are capable of inducing tumor sphere formation in vitro and tumorigenesis in the xenograft model (Fig. 1B and C). On the other hand, FACS analysis showed that the CD133 rich subpopulations were observed in Cal72 SLCICs (2.05 and 16.12\%) and tumor sample (18.31 and 48.48\%). Furthermore, Soufizomorrod et al (22) and Bertolini et al (23) also found the subpopulation of CD133+ cells in A459 (lung adenocarcinoma) and umbilical cord blood derived hematopoietic stem cells. CD133 expressed Cal72 SLCICs induced high grade tumor which was analyzed by a near infrared 2-DG optical imaging system on the basis of their intensity in nude mouse (Fig. 1C) which is parallel to the findings of Kovar et al (26). In the present study, quantitative transcript levels in cancer stem cells showed the CD133 expression in Cal72 and SaOS-2 SLCICs in vitro (Fig. 1E). Importantly, Shmelkov et al (25) reported quantitative expression of $\mathrm{CD} 133^{+/}$in human metastatic colon cancer through a xenograft model in nude mouse.

MCD as a major phenomenon observed in number of malignancies during abnormal mitosis checkpoints and apoptosis $(27,28)$. To determine mitotic catastrophe and cell death, SLCICs were treated with Dox and the phyto-drug BRM270, which later were stained with Hoechst 33342 to measure the shape of the nuclear DNA. The stained cells, confirmed cell shrinkage, apoptosis and cell death (Fig. 2B) which is supported by Blank et al (27). Castedo et al (28) and Kerr et al (29) also reported that DNA damage and multi-nucleation due to mitotic catastrophe and apoptosis in oncogenesis. While examining the mechanism of action of BRM270 in the SLCICs model of tumorigenesis, it was observed that treatment with BRM270 results in rapid and extensive apoptosis (Figs. 2B and 4A and B). These results suggest a novel NF- $\kappa \mathrm{B}$ inhibition-induced cell death response in SLCICs. Phytodrugs including BRM270 play a novel anti-proliferative role in many cancers (15-19). BRM270 is also effective against Dox resistant cancer cells inducing cell cycle arrest at G2/M phase in the $\mathrm{CD}_{133}{ }^{+}$expressing SLCICs Cal72. BRM-270 has shown significant efficacy in Dox-resistant cancer cells. The regulation of cell cycle in CSC is one of the most effective antitumor mechanisms by inhibition of uncontrolled cell growth. The G2/M transition is a crucial step in the cell cycle for controlling cell proliferation $(30,31)$. The G2/M checkpoint has been reported to block the entry into mitosis when DNA is damaged by natural products (30). BRM270 also caused DNA damage and cell cycle transition from G0-G1 phase to $\mathrm{G} 2 / \mathrm{M}$ phase (15.49 and 27.06\%) in the CD133+ expressing Cal72 and SaOS-2 SLCICs (Fig. 3). Furthermore, UCC is a morphological hallmark of premature mitosis that is typical of cells with a defective G2/M checkpoint $(27,32)$. Our results demonstrate a clear distinction between the mechanisms that drive neoplasia due to overexpression of stemness, oncogenic candidate genes which can markedly be mitigated by the $\mathrm{NF}-\kappa \mathrm{B}$ inhibitor BRM270. 
The present study represents an attempt to demonstrate the mechanism of $\mathrm{NF}-\kappa \mathrm{B}$ signaling cascade by induction via LPS. LPS-induced overexpression of IL- 6 enhanced the Cdk6 and p65 nuclear translocation in Cal72 SLCICs in the present study (Fig. 6A and F). Our finding on LPS-induced overexpression of IL- 6 and its effective role in NF- $\kappa \mathrm{B}$ signaling is also supported by Urashima et al (13) and Szczepanski et al (33) reporting that LPS binding with TLR4 on tumor cells enhance proliferation via inducing $N F-\kappa B$ translocation and production $(\mathrm{P}<0.05)$. Importantly, the distinct morphology of apoptosis was observed after exposure to BRM270 in both Cal72 and SaOS-2 SLCICs (Fig. 2A and B). In this study, it was revealed that BRM270 triggered apoptosis and downregulated the chromatin SMC2 in NF- $\mathrm{SB}$ pathway of tumorigenesis (Fig. 4B). Similarly, caspases are interleukin-1 $\beta$ converting enzyme family that initiates apoptosis in mammalian cells (34). The increased protein levels of cleaved Casp-8 at $24 \mathrm{~h}$ after BRM270 treatment (Fig. 4B and C) confirming the apoptotic activity, and Kallenberger et al (34) while working with Casp-8, also support our findings. In the present study, LPS-induced overexpression of cytokine IL-6 is inhibited by BRM270 (Fig. 4B and D). Further it induced apoptosis and significantly suppressed the expression of chromatin structure maintaining gene SMC2 (Condensin-2) in both BRM270 with LPS and BRM270 treated Cal72 SLCICs (Fig. 4B and E). Although, Hennessy et al (35) demonstrated that the LPS-mediated lethal shock induced oversecretion of IL-6 in vivo mouse-model, which was reduced in CDK6-deficient mice. In addition, LPS stimulation results in an increase in $\mathrm{NF}-\kappa \mathrm{B}$ production via IL- 6 oversecretion and subsequent pro-inflammatory response (36). This result indicated that LPS can stimulate IL-6 production via regulation of Cdk6 and $N F-\kappa B$ regulation. The validation of novel mechanism of IL- 6 mediated activation of $N F-\kappa B$ signaling cascade was confirmed by the exposure of Cal72 with LPS. Later it led to phosphorylation and activation of the kinase complex composed of IKK $\alpha$, IKK $\beta$ and STAT3 (37). BRM270 inhibits the significant expression of Cdk6 and IL-6 with signaling of NF- $\kappa$ B. Conclusively, taken together, our study indicates that BRM270 is an effective apoptotic augmenter and an anticancer phyto-drug.

In this study, we have provided evidence that IL-6 induces the activation of $\mathrm{NF}-\kappa \mathrm{B}$, an important proinflammatory pathway in cancer progression and tumorigenesis $(14,37)$. Significantly increased expression of CDK6 and NF- $\kappa \mathrm{B}$ in untreated group is complimented by Handschick et al (20) (Figs. 5A and B and 6F). CDK6 interacts and co-localizes with $N F-\kappa B$ because it is a chromatin-bound cofactor for NF- $\kappa$ Bdependent gene expression (20). A significant increase of IL-6 with NF- $\kappa \mathrm{B}$ observed in the CD133-overexpressing Cal72 SLCICs during the present study compliment the above earlier reports (Fig. 6A). Similarly, a significant increase in phosphatase activity observed in the IL-6-overexpressing Cal72 and SaOS-2 SLCICs compared with control versus BRM270 treated (Figs. 5A and B, 6A and 7) is parallel with the findings of Handschick et al (20) and Chanchevalap et al (36). In the present study, BRM270 was reported as an inhibitor of the IL-6-induced phospho-Rel family pathway. It is reported to abolish the activation of the NF- $\kappa \mathrm{B}$ pathway by targeting IL- 6 and Cdk6 in a dose-dependent manner. Furthermore, efficacy of BRM270 exerts the high cell cytotoxicity in MDR-CD133+ cell surface bearing potent SLCICs (Fig. 2A-C). These data suggest that strategies aimed at the co-targeting of $\mathrm{Cdk6/NF- \kappa B}$ activation and interaction between them might represent an attractive and novel approach to combat neoplasia. Although, drug resistance in $\mathrm{CD}_{133^{+}}$expressing SLCICs may be attributable to the persistence of a subpopulation of CSCs that exhibits MDR in lung cancer $(25,38)$. In the present study, it was observed that $\mathrm{CD}_{133^{+}}$rich populations of SLCICs are tumor inducing cells (Fig. 1C) which overexpress the nuclear factor- $\kappa \mathrm{B}$ signal trafficking genes $\mathrm{NF}-\kappa \mathrm{B}$ and Cdk6 along with stemness containing marker proteins CD133 and Oct3/4 (Figs. 1A and E and 2E). Notably, these cells exerted drug resistance under in vitro conditions against the Dox while BRM270 revealed stronger cytotoxicity (Fig. 2A and B). Our findings demonstrate that BRM270 downregulates the overexpression of IL-6 which induced Cdk6 to activate the apoptotic protein Casp-8 in both SaOS-2 and Cal72 SLCICs (Fig. 5B, C and F). Similarly, immunoblotting activity revealed the significantly increased level in non-treated group with respect to treated samples of both SaOS-2 and Cal72 SLCICs (Fig. 6A). Notably, in our results BRM270 significantly upregulates the I $\kappa \mathrm{B} \alpha$ in SLCICs (Figs. 5D and 6B). It further, downregulates the $\mathrm{NF}-\kappa \mathrm{B}$ protein and blocks the translocation of NF- $\kappa \mathrm{B}$ into the nucleus and suppresses the expression of IL-6 (Figs. 4B, 5C and 6A). This finding is in line with the results from Yan et al (39). It is interesting to note that once activated, JAKs phosphorylate, activate I $\mathrm{B} \alpha$ and Rel family protein, promoting its dimerization and translocation to the nucleus (40). Moreover, overexpressed IL-6 triggers STAT3 this simultaneously regulates I $\kappa \mathrm{B} \alpha$ during its dormant state in the cytoplasm $(40,41)$. Furthermore, LPS-mediated lethal shock, which is largely due to rapid release of inflammatory cytokines and chemokines including IL-6, was reduced in CDK6-deficient mice (36). We also found that LPS induced activated p65 overexpressing SLCICs causing a significant increase in Cal72 SLCICs proliferation while enhancing their pluripotent phenotype (Figs. 1B, 6A and 7) and resistance to drug by blot analysis (Figs. 2A and B and 6A). The combined efficacy of BRM270 phyto-drug on SLCICs with LPS and without distinctly indicating that it can be markedly inhibit the $\mathrm{NF}-\kappa \mathrm{B}$ induction and suppressed the Cdk6 to arrest the cell cycle in G1 phase and transit to G2/M checkpoint (Figs. 3 and 6A). Similarly, Chinese MST press (15) and Cao et al $(16,17)$ have revealed the more clear potentiality of BRM270 phyto-drug in different inflammatory conditions and cancers. Notably, we have shown that the co-overexpression of NF- $\kappa \mathrm{B}$ and Cdk6 in Cal72 SLCICs aggravates MDR as reported by Handschick et al (20). BRM270 significantly suppressed, fragmented DNA and caused programmed cell death (Figs. 2B and 6F). Furthermore, our study shows that $\mathrm{NF}-\kappa \mathrm{B}$, in association with Cdk6 and IL-6, plays an important role in regulation and gene expression. Similarly, CDK6 regulates $\mathrm{NF}-\kappa \mathrm{B}$-dependent target gene expression in most of chronic inflammation and neoplasia (42). Since blocking of the activity of $\mathrm{NF}-\kappa \mathrm{B}$ has become a primary target for drug therapy in a number of different diseases. It is important to understand what kind of effects it may have on genes which are negatively regulated by $\mathrm{NF}-\kappa \mathrm{B}$ and on the efficacy of the therapy itself. 
This present study demonstrates compelling evidence to downregulate the master regulator NF- $\mathrm{kB}$ with $\mathrm{Cdk6}$ by BRM270 as a novel inhibitor. To define the wide range of efficacy of BRM270, we studied SaOS-2 and Cal72 SLCICs compared to the effect on normal cells in hBMCs. Our findings aid in the identification of direct targets of molecular diatomous mechanism of carcinogenesis in CD133 expressing SLCICs. This knowledge can be significantly clinically relevant and will act as a base for the development of new therapeutic strategies.

\section{Acknowledgements}

This study was supported by the Basic Science Research Program of Avian Spermatogonial stem cells (SCs) grant no. NRF-2010-0023164 from National Research Foundation of Korea.

\section{References}

1. Chen K, Huang YH and Chen JL: Understanding and targeting cancer stem cells: Therapeutic implications and challenges. Acta Pharmacol Sin 34: 732-740, 2013.

2. Schober M and Fuchs E: Tumor-initiating stem cells of squamous cell carcinomas and their control by TGF- $\beta$ and integrin/focal adhesion kinase (FAK) signaling. Proc Natl Acad Sci USA 108: 10544-10549, 2011.

3. Woodward WA and Sulman EP: Cancer stem cells: Markers or biomarkers? Cancer Metastasis Rev 27: 459-470, 2008.

4. Dou J and Gu N: Biomarkers of cancer stem cells. Advances in Cancer Stem Cell Biology. Springer-International Publisher, Verlag, New York, pp45-67, 2012.

5. Horn PA, Tesch H, Staib P, Kube D, Diehl V and Voliotis D: Expression of AC133, a novel hematopoietic precursor antigen, on acute myeloid leukemia cells. Blood 93: 1435-1437, 1999.

6. Sanai N, Alvarez-Buylla A and Berger MS: Neural stem cells and the origin of gliomas. N Engl J Med 353: 811-822, 2005.

7. Shmelkov SV, St Clair R, Lyden D and Rafii S: AC133/CD133/ Prominin-1. Int J Biochem Cell Biol 37: 715-719, 2005.

8. Mizrak D, Brittan M and Alison M: CD133: Molecule of the moment. J Pathol 214: 3-9, 2008.

9. Khan Z, Shervington A, Munje C and Shervington L: The complexity of identifying cancer stem cell biomarkers. Cancer Invest 31: 404-411, 2013.

10. Hahn WC and Weinberg RA: Modelling the molecular circuitry of cancer. Nat Rev Cancer 2: 331-341, 2002.

11. Vogelstein B and Kinzler KW: Cancer genes and the pathways they control. Nat Med 10: 789-799, 2004.

12. Iliopoulos D, Hirsch HA and Struhl K: An epigenetic switch involving NF-kappaB, Lin28, Let-7 MicroRNA, and IL6 links inflammation to cell transformation. Cell 139: 693-706, 2009.

13. Urashima M, Teoh G, Chauhan D, Hoshi Y, Ogata A, Treon SP, Schlossman RL and Anderson KC: Interleukin-6 overcomes p $21^{\text {WAF1 }}$ upregulation and G1 growth arrest induced by dexamethasone and interferon-gamma in multiple myeloma cells. Blood 90: 279-289, 1997.

14. Sansone $P$ and Bromberg J: Targeting the interleukin-6/Jak/stat pathway in human malignancies. J Clin Oncol 30: 1005-1014, 2012.

15. Chinese Pharmacopeia Commission (CPC): Pharmacopoeia of the People's Republic of China. Chinese Medical Science and Technology Press, Beijing, p263, 2010.

16. Cao Z, Lin W, Huang Z, Chen X, Zhao J, Zheng L, Ye H, Liu Z, Liao L and Du J: Ethyl acetate extraction from a Chinese herbal formula, Jiedu Xiaozheng Yin, inhibits the proliferation of hepatocellular carcinoma cells via induction of G0/G1 phase arrest in vivo and in vitro. Int J Oncol 42: 202-210, 2013.

17. Cao Z, Lin W, Huang Z, Chen X, Zhao J, Zheng L, Ye H, Liu Z, Liao L and Du J: Jiedu Xiaozheng Yin, a Chinese herbal formula, inhibits tumor angiogenesis via downregulation of VEGF-A and VEGFR-2 expression in vivo and in vitro. Oncol Rep 29: 1080-1086, 2013.

18. Zhang B, Yuan Q, Huang L, Liu X, Li X, Lin S, Chen M and Ge X: Locality identification of Chinese medicinal plant Scutellaria baicalensis (Lamiaceae) population-level DNA barcoding]. Zhongguo Zhong Yao Za Zhi 37: 1100-1106, 2012 (In Chinese).
19. Kowalczyk E, Krzesiński P, Kura M, Niedworok J, Kowalski J and Błaszczyk J: Pharmacological effects of flavonoids from Scutellaria baicalensis. Przegl Lek 63: 95-96, 2006 (In Polish).

20. Handschick K, Beuerlein K, Jurida L, Bartkuhn M, Müller H, Soelch J, Weber A, Dittrich-Breiholz O, Schneider H, Scharfe M, et al: Cyclin-dependent kinase 6 is a chromatin-bound cofactor for NF-кB-dependent gene expression. Mol Cell 53: 193-208, 2014.

21. Prince ME, Sivanandan R, Kaczorowski A, Wolf GT, Kaplan MJ, Dalerba P, Weissman IL, Clarke MF and Ailles LE: Identification of a subpopulation of cells with cancer stem cell properties in head and neck squamous cell carcinoma. Proc Natl Acad Sci USA 104: 973-978, 2007.

22. Soufizomorrod M, Soleimani M, Hajifathali A, Mohammadi MM and Abroun S: Expansion of CD133(+) umbilical cord blood derived hematopoietic stem cells on a biocompatible microwells. Int J Hematol Oncol Stem Cell Res 7: 9-14, 2013.

23. Bertolini G, Roz L, Perego P, Tortoreto M, Fontanella E, Gatti L, Pratesi G, Fabbri A, Andriani F, Tinelli S, et al: Highly tumorigenic lung cancer $\mathrm{CD} 133^{+}$cells display stem-like features and are spared by cisplatin treatment. Proc Natl Acad Sci USA 106: 16281-16286, 2009.

24. Peickert S, Waurig J, Dittfeld C, Dietrich A, Garbe Y, Kabus L, Baumann M, Grade M, Ried T and Kunz-Schughart LA: Rapid re-expression of CD133 protein in colorectal cancer cell lines in vitro and in vivo. Lab Invest 92: 1607-1622, 2012.

25. Shmelkov SV, Butler JM, Hooper AT, Hormigo A, Kushner J, Milde T, St Clair R, Baljevic M, White I, Jin DK, et al: CD133 expression is not restricted to stem cells, and both $\mathrm{CD}_{13}{ }^{+}$and CD133-metastatic colon cancer cells initiate tumors. J Clin Invest 118: 2111-2120, 2008.

26. Kovar JL, Volcheck W, Sevick-Muraca E, Simpson MA and Olive DM: Characterization and performance of a near-infrared 2-deoxyglucose optical imaging agent for mouse cancer models. Anal Biochem 384: 254-262, 2009.

27. Blank M, Lerenthal Y, Mittelman L and Shiloh Y: Condensin I recruitment and uneven chromatin condensation precede mitotic cell death in response to DNA damage. J Cell Biol 174: 195-206, 2006.

28. Castedo M, Perfettini JL, Roumier T, Valent A, Raslova H, Yakushijin K, Horne D, Feunteun J, Lenoir G, Medema R, et al: Mitotic catastrophe constitutes a special case of apoptosis whose suppression entails aneuploidy. Oncogene 23: 4362-4370, 2004.

29. Kerr JF, Wyllie AH and Currie AR: Apoptosis: A basic biological phenomenon with wide-ranging implications in tissue kinetics. Br J Cancer 26: 239-257, 1972.

30. Luk SC, Siu SW, Lai CK, Wu YJ and Pang SF: Cell cycle arrest by a natural product via $\mathrm{G} 2 / \mathrm{M}$ checkpoint. Int J Med Sci 2: 64-69, 2005.

31. Xue Y, Ren H, Xiao W, Chu Z, Lee JJ and Mao L: Antitumor activity of AZ64 via G2/M arrest in non-small cell lung cancer. Int J Oncol 41: 1798-1808, 2012.

32. Roninson IB, Broude EV and Chang BD: If not apoptosis, then what? Treatment-induced senescence and mitotic catastrophe in tumor cells. Drug Resist Updat 4: 303-313, 2001.

33. Szczepanski MJ, Czystowska M, Szajnik M, Harasymczuk M, Boyiadzis M, Kruk-Zagajewska A, Szyfter W, Zeromski J and Whiteside TL: Triggering of Toll-like receptor 4 expressed on human head and neck squamous cell carcinoma promotes tumor development and protects the tumor from immune attack. Cancer Res 69: 3105-3113, 2009.

34. Kallenberger SM, Beaudouin J, Claus J, Fischer C, Sorger PK, Legewie S and Eils R: Intra-and interdimeric caspase-8 selfcleavage controls strength and timing of CD95-induced apoptosis. Sci Signal 7: 14 ra23, 2014. doi: 10.1126/scisignal.2004738.

35. Hennessy EJ, Sheedy FJ, Santamaria D, Barbacid M and O'Neill LA: Toll-like receptor-4 (TLR4) downregulates microRNA-107, increasing macrophage adhesion via cyclindependent kinase 6. J Biol Chem 286: 25531-25539, 2011.

36. Chanchevalap S, Nandan MO, McConnell BB, Charrier L, Merlin D, Katz JP and Yang VW: Kruppel-like factor 5 is an important mediator for lipopolysaccharide-induced proinflammatory response in intestinal epithelial cells. Nucleic Acids Res 34: 1216-1223, 2006.

37. De Simone V, Franzè E, Ronchetti G, Colantoni A, Fantini MC, Di Fusco D, Sica GS, Sileri P, MacDonald TT, Pallone F, et al: Th17-type cytokines, IL- 6 and TNF- $\alpha$ synergistically activate STAT3 and NF- $\kappa$ B to promote colorectal cancer cell growth. Oncogene: Sep 1, 2014 (Epub ahead of print). doi: 10.1038/ onc.2014.286. 
38. Sarvi S, Mackinnon AC, Avlonitis N, Bradley M, Rintoul RC, Rassl DM, Wang W, Forbes SJ, Gregory CD and Sethi T: CD133 cancer stem-like cells in small cell lung cancer are highly tumorigenic and chemoresistant but sensitive to a novel neuropeptide antagonist. Cancer Res 74: 1554-1565, 2014.

39. Yan HQ, Huang XB, Ke SZ, Jiang YN, Zhang YH, Wang YN, $\mathrm{Li} \mathrm{J}$ and Gao FG: Interleukin 6 augments lung cancer chemotherapeutic resistance via ataxia-telangiectasia mutated/NF-kappaB pathway activation. Cancer Sci 105: 1220-1227, 2014.

40. Lee JJ, Kim HJ, Yang CS, Kyeong HH, Choi JM, Hwang DE, Yuk JM, Park K, Kim YJ, Lee SG, et al: A high-affinity protein binder that blocks the IL-6/STAT3 signaling pathway effectively suppresses non-small cell lung cancer. Mol Ther 22: 1254-1265, 2014.
41. McFarland BC, Hong SW, Rajbhandari R, Twitty GB Jr, Gray GK, Yu H, Benveniste EN and Nozell SE: NF- $\kappa$ B-induced IL-6 ensures STAT3 activation and tumor aggressiveness in glioblastoma. PLoS One 8: e78728, 2013.

42. Buss H, Handschick K, Jurrmann N, Pekkonen P, Beuerlein K, Müller H, Wait R, Saklatvala J, Ojala PM, Schmitz ML, et al: Cyclin-dependent kinase 6 phosphorylates NF- $\kappa$ B P65 at serine 536 and contributes to the regulation of inflammatory gene expression. PLoS One 7: 1-13, 2012. 